Selected Papers from the 2nd Radiocarbon in the Environment Conference, Debrecen, Hungary, 3-7 July 2017 (C) 2018 by the Arizona Board of Regents on behalf of the University of Arizona. This is an Open Access article, distributed under the terms of the Creative Commons Attribution licence (http://creativecommons.org/licenses/ by/4.0/), which permits unrestricted re-use, distribution, and reproduction in any medium, provided the original work is properly cited.

\title{
GLOBAL AND REGIONAL EMISSIONS OF RADIOCARBON FROM NUCLEAR POWER PLANTS FROM 1972 TO 2016
}

\author{
G Zazzeri $^{1 *} \cdot$ E Acuña Yeomans ${ }^{1} \cdot$ H D Graven ${ }^{1}$
}

Department of Physics, Imperial College London, South Kensington Campus, London SW7 2AZ, United Kingdom.

\begin{abstract}
CH}_{4}$ and $\mathrm{CO}_{2}$ emissions from geologic sources, which are devoid of radiocarbon $\left({ }^{14} \mathrm{C}\right)$, dilute the atmospheric ${ }^{14} \mathrm{C} / \mathrm{C}$ ratio. Observations of ${ }^{14} \mathrm{C} / \mathrm{C}$ can be used to estimate fossil fuel-derived $\mathrm{CH}_{4}$ and $\mathrm{CO}_{2}$. However, the atmospheric ${ }^{14} \mathrm{C} / \mathrm{C}$ ratio is perturbed by emissions of ${ }^{14} \mathrm{C}$ from nuclear power plants (NPPs) and fuel reprocessing sites, which may affect such ${ }^{14} \mathrm{C} / \mathrm{C}$-based estimation if they are not correctly quantified. We calculate NPP ${ }^{14} \mathrm{C}$ emissions for $\mathrm{CO}_{2}$ and $\mathrm{CH}_{4}$ from $1972-2016$ using standard emission factors $\left({ }^{14} \mathrm{C}\right.$ emitted per unit of power produced) and analyze trends in global and regional emissions. We use available observations of ${ }^{14} \mathrm{C}$ emissions and power generation in Europe to assess emission factors for different reactor types, as well as potential differences related to the age or manufacturer of the NPPs. Globally, nuclear ${ }^{14} \mathrm{C}$ emissions increase until 2005 and then decrease, mostly because of the closure of gas-cooled reactors in the United Kindom and the shutdown of light water reactors after the Fukushima nuclear accident in March 2011. Observed emission factors in Europe show strong variability, spanning values from 0.003 to $2.521 \mathrm{TBq} / \mathrm{GWa}$ for PWR and from 0.007 to $1.732 \mathrm{TBq} / \mathrm{GWa}$ for BWR reactors, suggesting more information and more sophisticated models are needed to improve estimates of ${ }^{14} \mathrm{C}$ emissions.
\end{abstract}

KEYWORDS: nuclear power plants, radiocarbon emissions.

\section{INTRODUCTION}

Carbon dioxide $\left(\mathrm{CO}_{2}\right)$ and methane $\left(\mathrm{CH}_{4}\right)$ are the two most important anthropogenic greenhouse gases contributing to climate change (IPCC 2013). In order to mitigate climate change, the 2015 Paris climate agreement stresses the need for reaching a "balance" between anthropogenic emissions and removal of greenhouse gases by the second half of this century (Rogelj et al. 2016), which will require strong reductions in emissions (Shindell et al. 2012; IPCC 2013). Anthropogenic emissions of $\mathrm{CO}_{2}$ and $\mathrm{CH}_{4}$ come from both biogenic and fossil sources, and understanding the relative contribution of sources to the global $\mathrm{CO}_{2}$ and $\mathrm{CH}_{4}$ emissions is fundamental to underpin mitigation policies. However, the source apportionment between biogenic and fossil sources of $\mathrm{CO}_{2}$ and $\mathrm{CH}_{4}$, and between natural and anthropogenic sources and sinks, is still highly uncertain, particularly for $\mathrm{CH}_{4}$ (Nisbet et al. 2016; Schwietzke et al. 2016). The short lifetime and large warming potential of $\mathrm{CH}_{4}$ have led to a strong emphasis on $\mathrm{CH}_{4}$ emissions mitigation in the Paris Agreement targets for the next 10-15 years (Shindell et al. 2012), amplifying the need for improved understanding of $\mathrm{CH}_{4}$ emissions.

Atmospheric ${ }^{14} \mathrm{C}$ measurements have been widely used for estimation of the fossil-fuel fraction of $\mathrm{CO}_{2}$ and $\mathrm{CH}_{4}$. When emitted to the atmosphere, carbon from fossil fuels, which is devoid of ${ }^{14} \mathrm{C}$, causes a dilution of the atmospheric ${ }^{14} \mathrm{C} / \mathrm{C}$ ratio $\left(\Delta^{14} \mathrm{C}\right.$, Stuiver and Polach 1977) that can be measured. $\Delta^{14} \mathrm{CO}_{2}$ observations at "clean-air" and polluted atmospheric monitoring sites have been used to estimate fossil fuel-derived $\mathrm{CO}_{2}$ over urban and continental regions (e.g. Levin et al. 2008; Turnbull et al. 2009; Miller et al. 2012), and long-term $\Delta^{14} \mathrm{CH}_{4}$ observations currently provide the main constraint on the global fossil fraction of $\mathrm{CH}_{4}$ emissions (Lassey et al. 2007a, 2007b; Kirschke et al. 2013). However, anthropogenic emissions of ${ }^{14} \mathrm{C}$ from nuclear power plants (NPPs) may affect ${ }^{14} \mathrm{C} / \mathrm{C}$-based estimation of fossil-derived $\mathrm{CO}_{2}$ and $\mathrm{CH}_{4}$ emissions if $\mathrm{NPP}$ emissions are not correctly quantified (Lassey et al. 2007a, 2007b; Graven and Gruber 2011).

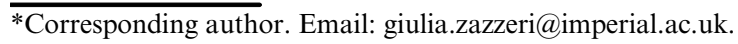


The production and release of ${ }^{14} \mathrm{C}$ from NPPs depends on the type of reactor used. The two main reactor designs are both "Light Water" reactors, which use water both as neutron moderator and coolant. The two designs are pressurized water reactors (PWRs) and boiling water reactors (BWRs). PWRs consist of two circuits, the primary cooling/heat transfer circuit with pressurized water and a secondary circuit where steam is generated, whereas BWRs have one circuit for both (EPRI 2010). Other reactor designs include British Magnox gas-cooled reactors (GCRs), using graphite as the neutron moderator and carbon dioxide as the primary coolant, advanced gas-cooled reactors (AGRs), the second generation of British gas-cooled reactors, pressurized heavy water reactors (HWRs), using heavy water as moderator, and light water graphite reactors (LWGRs), of Russian design.

Production of ${ }^{14} \mathrm{C}$ occurs through nuclear reactions involving the parent isotopes ${ }^{14} \mathrm{~N},{ }^{17} \mathrm{O}$, and ${ }^{13} \mathrm{C}$ in the nuclear fuel, coolant and structural material of the reactor (Yim and Caron 2006). Heavy water reactors (HWRs), predominantly in Canada, and gas-cooled reactors (Magnox GCRs and AGCRs) in the UK emit much more ${ }^{14} \mathrm{C}$ for the same amount of electrical power generation than other reactor types. Most of the ${ }^{14} \mathrm{C}$ produced in HWRs results from the large amount of ${ }^{17} \mathrm{O}$ in the heavy-water moderator, while ${ }^{14} \mathrm{C}$ emissions in the gas-cooled reactors come from the purification of the $\mathrm{CO}_{2}$ circuits used to cool the reactor and from the isotopic exchange between the graphite and the $\mathrm{CO}_{2}$ circuit (Dubourg 1998). In PWRs, the most common type of NPP in use today, gaseous ${ }^{14} \mathrm{C}$ effluents are mostly in the form ${ }^{14} \mathrm{CH}_{4}(70-95 \%$ ) (Kunz 1985), due to the reducing chemistry of the reactor coolant, whereas in all other reactor types the gaseous ${ }^{14} \mathrm{C}$ effluent is almost entirely ${ }^{14} \mathrm{CO}_{2}$.

Estimates of ${ }^{14} \mathrm{C}$ emissions are conducted by measurements at some facilities (Van der Stricht and Janssens 2001, 2005) or estimated with information about the reactor (EPRI 2010). The European Commission reports yearly measurements of radioactive airborne and liquid discharges for each European NPP in the European Commission RAdioactive Discharges Database (RADD Database 2017). In the United States, reported ${ }^{14} \mathrm{C}$ emissions are typically not measured but only estimated according to recommendations by EPRI (EPRI 2010), which use a theoretical model for emissions of ${ }^{14} \mathrm{C}$ from light water reactors on the basis of the design, release pathways and unit-specific reactor core physics, including parameters such as the neutron flux profile, the mass of coolant in the active core and the concentration of nitrogen.

To estimate global ${ }^{14} \mathrm{C}$ emissions, emission factors based on electrical power production are typically used, due to the sparseness of ${ }^{14} \mathrm{C}$ atmospheric measurements from nuclear power facilities (Lassey et al. 2007a, 2007b; Graven and Gruber 2011). Globally, ${ }^{14} \mathrm{CO}_{2}$ production by NPPs is relatively small compared to natural production, about 11\% (Turnbull et al. 2009, Graven et al. 2012). However, regions where nuclear facilities are concentrated may contribute to an atmospheric ${ }^{14} \mathrm{C}$ enrichment both at local (Levin et al. 2003) and continental scale (Graven and Gruber 2011) that may offset the ${ }^{14} \mathrm{C}$ dilution by fossil fuel emissions. Vogel et al. (2013) investigated local ${ }^{14} \mathrm{CO}_{2}$ emissions from the nuclear industry in a hotspot region of Canada with multiple power plants, and highlighted how an underestimation of ${ }^{14} \mathrm{CO}_{2}$ emissions from NPPs may cause errors in the calculated fossil fuel derived $\mathrm{CO}_{2}$. The effect can also extend several hundred kilometres from NPP emissions, counteracting the regional decreases in $\Delta^{14} \mathrm{CO}_{2}$ caused by fossil fuel combustion (Graven and Gruber 2011).

In contrast to $\mathrm{CO}_{2}$, NPPs have a much stronger effect on the global inventory of ${ }^{14} \mathrm{CH}_{4}$ and uncertainty in NPP emissions is a primary limitation on the use of $\Delta{ }^{14} \mathrm{CH}_{4}$ as a fossil fuel tracer (Lassey et al. 2007a, 2007b). ${ }^{14} \mathrm{C}$ releases from PWRs increased the ${ }^{14} \mathrm{C} / \mathrm{C}$ ratio in $\mathrm{CH}_{4}$ in the period between 1987 and 1995, representing 20-40\% of the overall ${ }^{14} \mathrm{CH}_{4}$ budget (Quay et al. 1999). By using a time series of atmospheric $\Delta^{14} \mathrm{CH}_{4}$ from 1986 to 2000 guided by a mass balance approach, Lassey et al. (2007a, 2007b) determined a fraction of global $\mathrm{CH}_{4}$ emissions of fossil origin of $30.0 \pm 2.3 \%(1 \sigma)$ and an emission factor for ${ }^{14} \mathrm{CH}_{4}$ produced during nuclear 
power generation by PWRs of $0.286 \pm 0.026 \mathrm{TBq} \mathrm{GWe}^{-1} \mathrm{yr}^{-1}$. Eisma et al (1995) estimated an emission factor of $0.260 \pm 0.050 \mathrm{TBq} \mathrm{GWe}^{-1} \mathrm{yr}^{-1}$ for European PWRs using atmospheric $\Delta^{14} \mathrm{CH}_{4}$ measurements from a sampling station in the Netherlands.

Even though emission factors are commonly used to estimate ${ }^{14} \mathrm{C}$ emissions from NPPs, they may differ greatly both among sites and over time within the same site. Graven and Gruber (2011) gathered observations available from 45 reactor sites and reported emission factors spanning about a factor of two for different reactors of the same type, and for the same reactor in different years. Vogel et al. (2013) similarly found that mean emission factors and some yearto-year variations for individual HWRs in Ontario, Canada, varied by a factor of two. Additional analyses of potential causes for the variation in ${ }^{14} \mathrm{C}$ emission factors may help to refine the emission factors used and resulting emission factor-based ${ }^{14} \mathrm{C}$ emissions estimates.

In this paper we update the global NPP ${ }^{14} \mathrm{C}$ emission database of Graven and Gruber (2011) to cover the period 1972-2016 and use the emission factor-based estimates to analyze trends in NPP ${ }^{14} \mathrm{C}$ emissions for $\mathrm{CO}_{2}$ and $\mathrm{CH}_{4}$ globally and by region. We also include data on ${ }^{14} \mathrm{C}$ emitted from spent nuclear fuel reprocessing sites. We find that global ${ }^{14} \mathrm{C}$ emissions from NPPs and fuel reprocessing sites decreased over 2006-2016 due to the decommissioning of nuclear reactors mainly in the UK, Germany and Japan. Then we use available observations of ${ }^{14} \mathrm{C}$ emissions and power generation for each European nuclear site to assess emission factors for PWRs and BWRs and for the fraction of ${ }^{14} \mathrm{C}$ emitted as $\mathrm{CO}_{2}$, as well as potential differences in emission factors related to the age or manufacturer for PWRs. The emission factors for European PWRs show large variability, which is not explained by the reactor age or manufacturer, demonstrating large uncertainties in the emission factor approach to estimating ${ }^{14} \mathrm{C}$ emissions.

\section{METHODOLOGY}

We update the nuclear power plant electricity production database and associated ${ }^{14} \mathrm{C}$ emissions from Graven and Gruber (2011) to cover the period 1972-2016. Annual energy output for each reactor was compiled from the International Atomic Energy Agency's Power Reactor Information System (IAEA PRIS 2017). The emission factors from Graven and Gruber (2011) (Table 1), which are based on averages for 1990-1995 reported by UNSCEAR (2000), are used to calculate annual ${ }^{14} \mathrm{C}$ emissions from individual NPPs. Estimated annual ${ }^{14} \mathrm{CO}_{2}$ and ${ }^{14} \mathrm{CH}_{4}$ discharges are given for each nuclear site in $\mathrm{TBq} \mathrm{yr}^{-1}$ in Table S1, where we assume PWRs emit 72\% of the ${ }^{14} \mathrm{C}$ as $\mathrm{CH}_{4}$ and $28 \%$ of the ${ }^{14} \mathrm{C}$ as $\mathrm{CO}_{2}$ and all other reactor types emit all ${ }^{14} \mathrm{C}$ as $\mathrm{CO}_{2}$. Measured emissions from the Sellafield, La Hague (RADD Database 2017) and Tokai reprocessing

Table $1{ }^{14} \mathrm{C}$ emission factors for different reactor types with $70 \%$ confidence intervals from Graven and Gruber (2011). The confidence interval for the LWGR emission factor was not given by Graven and Gruber (2011) but we estimate it to be $\pm 0.8 \mathrm{TBq} / \mathrm{GWa}$ based on the fractional uncertainty found for other reactor types.

\begin{tabular}{ll}
\hline Reactor type & ${ }^{14} \mathrm{C}$ emission factor $(\mathrm{TBq} / \mathrm{GWa})$ \\
\hline PWR & $0.24[0.11-0.52]$ \\
BWR & $0.51[0.17,0.85]$ \\
AGR & $1.4[0.69,2.08]$ \\
Magnox GCR & $5.5[2.09,9.23]$ \\
LWGR & $1.3[0.5,2.1]$ \\
HWR & $1.6[0.27,7.04]$ \\
\hline
\end{tabular}


sites (UNSCEAR 2000; Nakada et al. 2008) are also included in Table S1, with ${ }^{14} \mathrm{C}$ emitted as $\mathrm{CO}_{2}$. Emissions from Tokai are available only until 2008 and we assumed no emissions after this. We do not include emissions from other fuel reprocessing sites, or ${ }^{14} \mathrm{C}$ produced by other activities such as medical applications for isotopes.

Emission factors were analyzed by comparing measured ${ }^{14} \mathrm{C}$ emissions $\left(\mathrm{GBq} \mathrm{yr}{ }^{-1}\right)$ for 71 European nuclear plants from the RADD database (RADD 2017), to the IAEA PRIS energy output data (IAEA PRIS 2017), on an annual basis. We bin data by country for 1995-2005 and 2006-2015 to examine differences in emission factors in different countries over time. Then, focusing on the 48 European PWRs with the most data available, we examine difference in emission factors for reactors of different ages. Three age intervals were chosen: $0-25,25-35$, and more than 35 years. Finally, we assess differences in emission factors for the 48 European PWRs from the four main manufacturers: VVER, Siemens, Areva, and Westinghouse.

For most NPPs, only total ${ }^{14} \mathrm{C}$ emissions are reported in RADD. However, emissions of ${ }^{14} \mathrm{CO}_{2}$ and ${ }^{14} \mathrm{CH}_{4}$ are reported separately for Spanish, Hungarian, and German reactors, and these data were used to calculate the ${ }^{14} \mathrm{CH}_{4}$ fraction for BWR and PWR reactors. The percentage of ${ }^{14} \mathrm{C}$ from non-methane hydrocarbons is not available, and therefore excluded from the analysis.

\section{RESULTS AND DISCUSSION}

\section{Global and Regional ${ }^{14} \mathrm{C}$ Emission Trends}

By estimating ${ }^{14} \mathrm{C}$ emissions using the emission factors in Table 1 with electricity production data, and including observed ${ }^{14} \mathrm{C}$ emissions from reprocessing plants, we find global total nuclear power plant ${ }^{14} \mathrm{C}$ emissions increased from 1972 to 2005 as the number of nuclear facilities expanded, but this trend recently reversed as a result of changes in nuclear energy production (Figure 1). The apparent emissions reduction after 2005 is mostly due to the closure of GCR-type reactors sited in the UK and the closure or temporary shutdown of PWR and BWR reactors in Germany and Japan after the Fukushima nuclear accident in March 2011 (Figure 1a). However, an uncertainty of $14-35 \%$ on the annual global ${ }^{14} \mathrm{C}$ estimate, based on the emission factors uncertainties in Table 1 and a Monte Carlo analysis, must be taken into account (see below).

Most ${ }^{14} \mathrm{C}$ emissions come from PWRs, even though the PWR emission factor is the lowest (Table 1), as PWRs are by far the most common type of reactor. On the other hand, because of the high emission factor, HWR type reactors produce $28 \%$ of total ${ }^{14} \mathrm{C}$ emissions, even though they represent only about $5 \%$ of the generating capacity of all current operating reactors today (Figure 1a). Emissions from HWRs showed the strongest increase over 2005-2015. Spent fuel reprocessing (SFR) contributes $0-32 \mathrm{TBq}$.

There are clear differences in ${ }^{14} \mathrm{C}$ emissions trends based on energy production by region in recent years (Figure 1b). We find emissions decreased in Europe, increased in Asia (except Japan) and remained approximately steady in the US and Canada. Emissions in Europe declined 36\% between 2005 and 2015. In the UK, 30 reactors have been decommissioned since 2003, mainly Magnox GCR-type, leading to an overall decline of $50 \%$ in ${ }^{14} \mathrm{C}$ emissions in the UK. Emissions in Germany decreased by 60\% since 1999, whereas in France nuclear power production remains steady, with 58 operable reactors. ${ }^{14} \mathrm{C}$ emissions from the Sellafield reprocessing plant also decreased, from a maximum value of $2.940 \mathrm{TBq}$ in 2000 to $0.420 \mathrm{TBq}$ in 2015. In contrast, total ${ }^{14} \mathrm{C}$ emissions from La Hague reprocessing plant in France increased, reaching $20.2 \mathrm{TBq}$ in 2015 . 

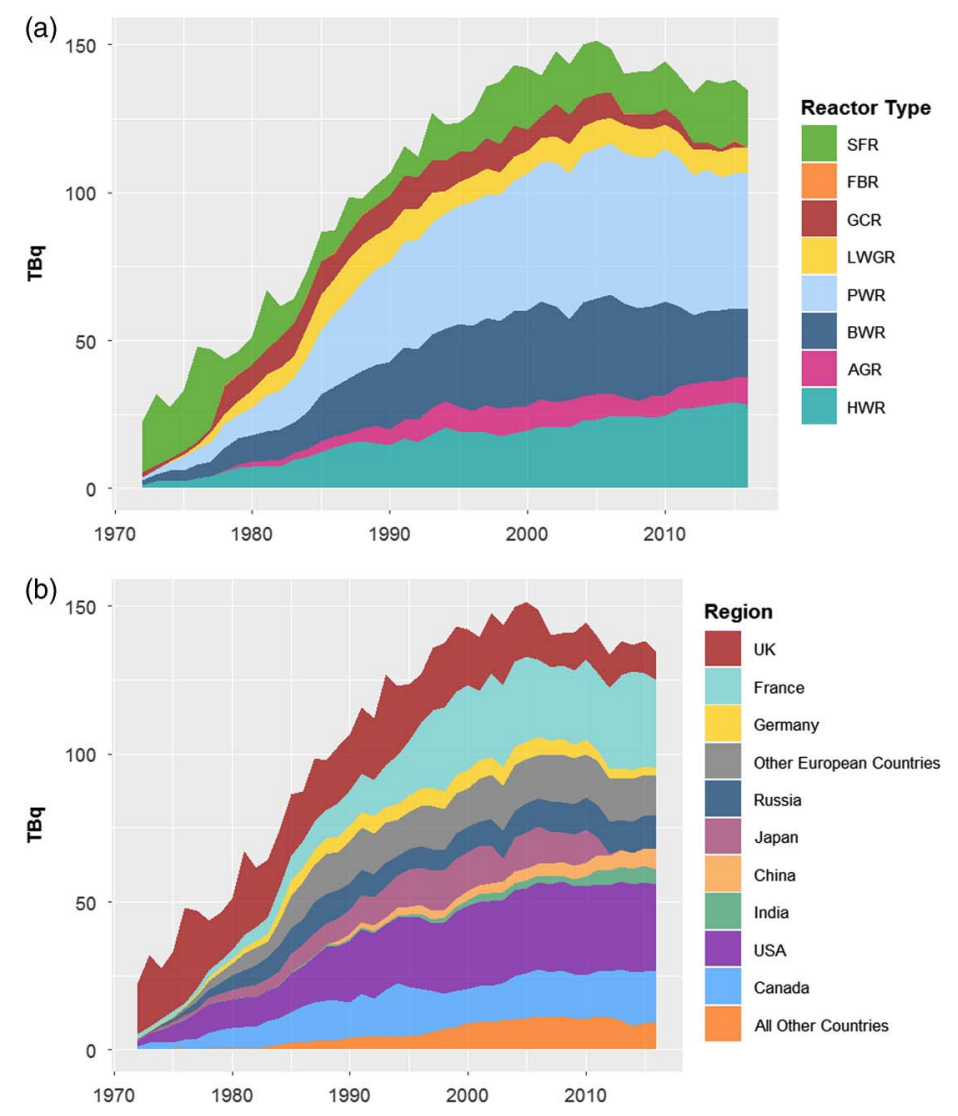

Figure 1 Global ${ }^{14} \mathrm{C}$ emissions from NPP, reprocessing plants (SFR) and fast breeder reactors (FBR) by (a) reactor type and (b) region. Other European countries include Armenia, Belgium, Bulgaria, Czech Republic, Finland, Hungary, Italy, Lithuania, Netherlands, Romania, Slovakia, Slovenia, Spain, Sweden, Switzerland, and Ukraine. All other countries include Argentina, Brazil, Mexico, South Africa, Pakistan, Kazakhstan, South Korea, and Iran.

The nuclear capacity in the United States accounts today for about $30 \%$ of the worldwide nuclear power generation and $26 \%$ of the ${ }^{14} \mathrm{C}$ emissions. Emissions from Canadian reactors, mainly HWRs, peaked in 2014 and decreased in 2016 by approximately 3\%. HWRs comprise the majority of the reactors in India, where the nuclear power generation was boosted in 2011 and remained approximately steady for the last 6 years. The nuclear capacity in China and North Korea has been progressively growing, and their NPPs currently account for $10 \%$ of global ${ }^{14} \mathrm{C}$ emissions, whereas emissions from Russia remained relatively constant after 2012 . In Japan, power production stopped at all NPPs in 2011-2012 after the Fukushima accident. Since then, 42 remain operational but have not yet resumed supplying energy (IAEA PRIS 2017), while 12 entered permanent shutdown as of 2016.

\section{Emission Factors from European Data}

Emission factors for European PWRs and BWRs calculated using observed ${ }^{14} \mathrm{C}$ emissions and power produced overlap the emission factors from Graven and Gruber (2011), but exhibit large variability (Tables 2 and 3; Figure 2). Emission factors are generally higher for Other European reactors than for German, Spanish, and British reactors. 
Table 2 Median emission factors calculated using radiocarbon measurements of the European nuclear facilities (RADD Database 2017) and their electricity production (IAEA PRIS 2017). The interquartile range is in square brackets.

\begin{tabular}{ll}
\hline Reactor type & $\begin{array}{l}1995-2015^{14} \mathrm{C} \text { median emission } \\
\text { factor }(\mathrm{TBq} / \mathrm{GWa})\end{array}$ \\
\hline PWR & $0.248[0.151-0.360]$ \\
BWR & $0.471[0.371-0.630]$ \\
GCR & $3.878[2.234-8.453]$ \\
AGR & $1.420[1.025-1.822]$ \\
\hline
\end{tabular}

Table 3 Median emission factors calculated using radiocarbon measurements of the European nuclear facilities (RADD Database 2017) and their electricity production (IAEA PRIS 2017). The interquartile range is in square brackets, and the number of NPPs included in the calculation in round brackets.

\begin{tabular}{llll}
\hline Location & $\begin{array}{l}\text { Reactor } \\
\text { type }\end{array}$ & $\begin{array}{l}1995-2005^{14} \mathrm{C} \text { median emission } \\
\text { factor }(\mathrm{TBq} / \mathrm{GWa})\end{array}$ & $\begin{array}{l}2006-2015^{14} \mathrm{C} \text { median emission } \\
\text { factor }(\mathrm{TBq} / \mathrm{GWa})\end{array}$ \\
\hline Germany & PWR & $0.193[0.108-0.284](13)$ & $0.256[0.185-0.321](11)$ \\
France & PWR & $0.209[0.208-0.210](19)$ & $0.209[0.208-0.210](19)$ \\
Spain & PWR & $0.049[0.042-0.050](1)$ & $0.161[0.076-0.232](4)$ \\
UK & PWR & $0.183[0.101-0.196](1)$ & $0.190[0.176-0.276](1)$ \\
Other Europe & PWR & $0.330[0.208-0.477](9)$ & $0.379[0.257-0.485](10)$ \\
Germany & BWR & $0.401[0.293-0.593](5)$ & $0.390[0.355-0.473](5)$ \\
Spain & BWR & - & $0.485[0.361-0.546](2)$ \\
Europe & BWR & $0.539[0.469-0.732](4)$ & $0.600[0.475-0.738](4)$ \\
\hline
\end{tabular}

In comparing reported ${ }^{14} \mathrm{C}$ emissions and electricity production in France, we found that the resulting emission factors were very consistent, suggesting the data reported for French reactors appear to be estimated on the basis of the power production rather than on measurements. The apparent emission factor in the French PWRs is 0.209 [0.208-0.210] and 0.209 [0.208-0.210] $\mathrm{TBq} / \mathrm{GWa}$ before and after 2005 respectively. We therefore omit the French data from our analysis of observed emission factors.

The median value of emission factors based on measurements taken after 2005 is slightly higher than the previous period for Other European PWR and BWRs and for German PWRs, whereas we might expect a decrease in the emission factors due to increasing efficiency of power plants. For Other European PWRs, this might be explained by the availability of more ${ }^{14} \mathrm{C}$ measurements from nuclear facilities with higher emission factors after 2005 than before 2005 (e.g. in Czech Republic, Sweden; Figure 3). Measurements from only one Spanish PWR were available before 2005.

From a closer look into the outliers in Figure 2, we found that the highest values, greater than $0.75 \mathrm{TBq} / \mathrm{GWa}$, are associated with very low energy production-i.e. maintenance periods or shutdown of the reactor-for German PWR reactors Biblis A and B (Figures 3 and S2). High emissions were found for some PWRs in certain years: Bohunice in Slovakia, Temelin in Czech Republic and Asco 1-2 and Vandellos in Spain. The emission factors for the Swedish reactor Ringhals 2, the oldest of the four reactors within the Ringhals nuclear plant, are consistently higher throughout the whole period of study (1995-2015) (Figures 3 and S2). ${ }^{14} \mathrm{C}$ releases from 

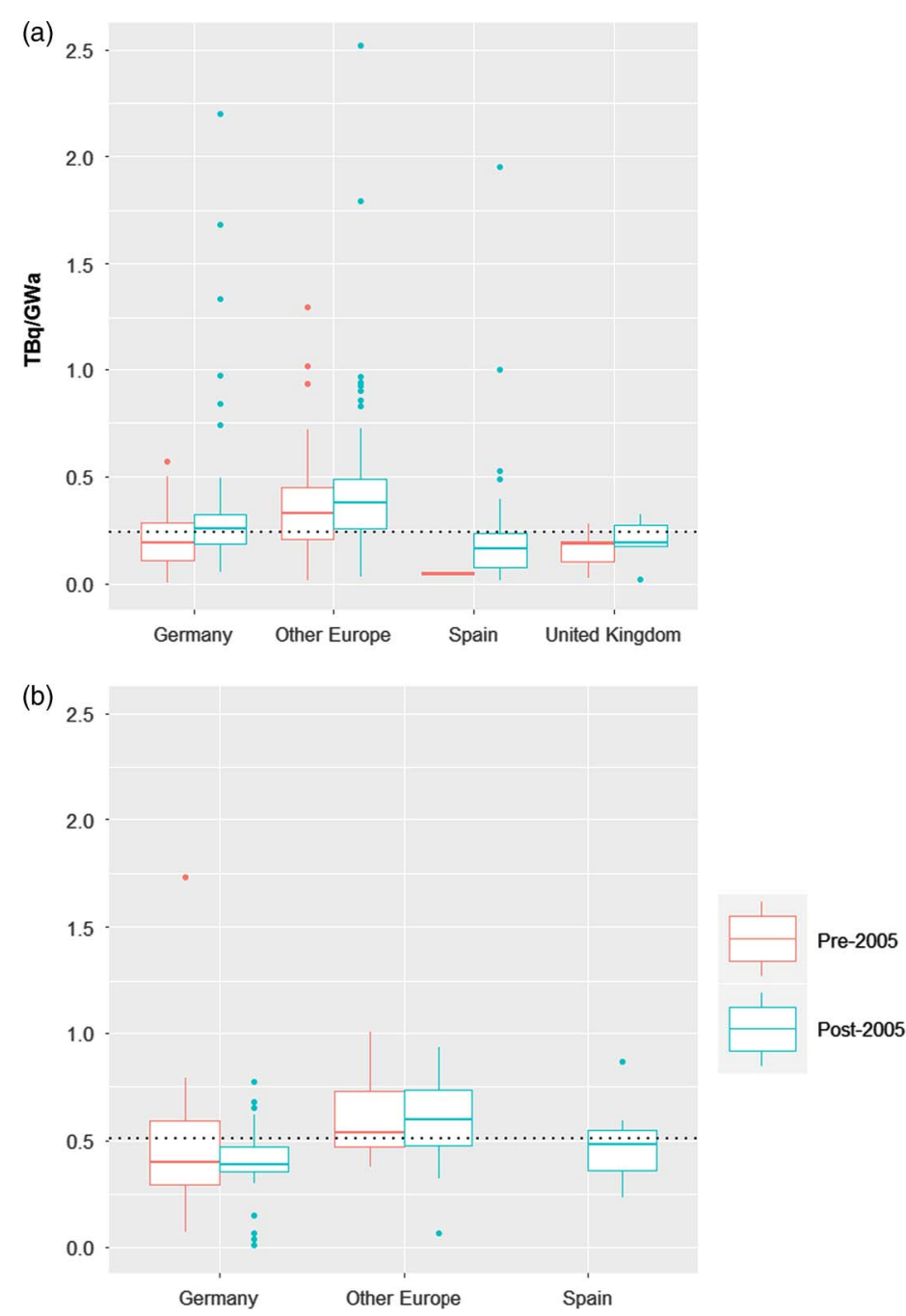

Figure 2 Emission factors for (a) PWR and (b) BWR calculated as the ratio of the measured ${ }^{14} \mathrm{C}$ emissions and the annual electricity supplied for 1995 2005 and for 2006-2015. Other Europe represents all European countries except Spain, Germany and the UK. Central lines in each box are the median values; the box is the interquartile range (IQR); dashed lines are emission factors from Graven and Gruber (2011). Outliers shown with circles are calculated as less than Q1 $-1.5^{*} \mathrm{IQR}$ and greater than Q3+1.5*IQR.

the Swedish NPP have been investigated in the study of Stenström et al. (1995), but measurements were taken only from reactors 1 and 4, which are characterized by a lower emission factor than Ringhals 2 in our analysis. For the PWR Ringhals 4 they observed a substantial increase of emissions during the venting of the reactor containment and gas decay tanks, where the cover gas from the primary system is compressed and stored before release, to allow for the decay of short-lived radionuclides. Venting operations were concurrent with provisional reactor outages, together with the total replacement of the cover gas in the primary coolant, which explains the persistence of ${ }^{14} \mathrm{C}$ releases in PWR reactors during temporary shutdown periods. A strong ${ }^{14} \mathrm{C}$ release during NPP shut-down events has also been found in other 


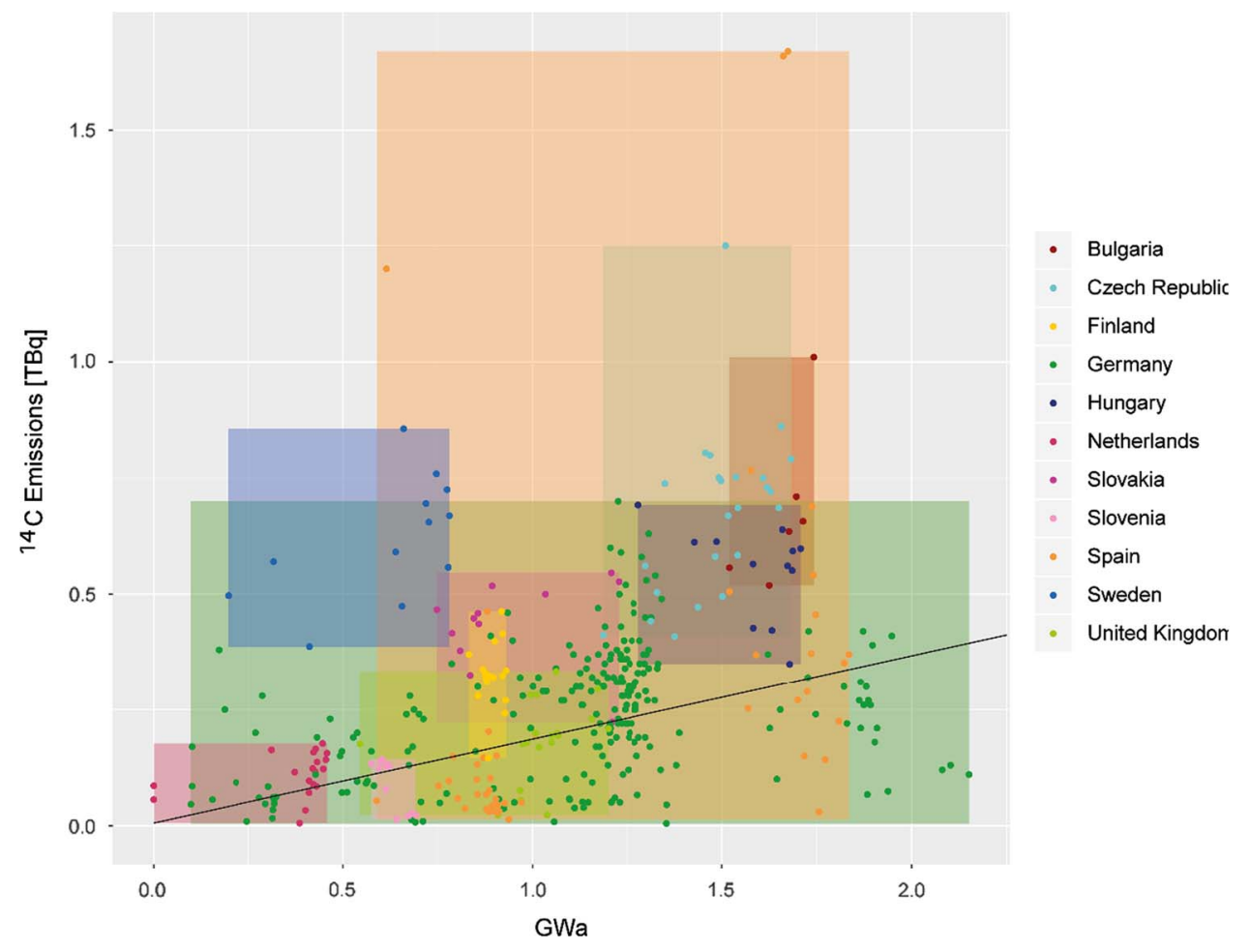

Figure 3 Annual ${ }^{14} \mathrm{C}$ emissions reported in the RADD database versus annual power production for PWRs in Europe, shown by country. Colored boxes enclose all data for each country. The line represents the PWR emission factor of $0.24 \mathrm{TBq} / \mathrm{GWa}$ (Table 1).

studies (Molnár et al. 2007; Vogel et al. 2013). However, after permanent shutdown of reactors, measured ${ }^{14} \mathrm{C}$ emissions decrease (e.g. Obrigheim reactor in Germany, Ignalina reactor in Lithuania, Sizewell reactor in the UK) (see Table S2).

The occurrence of ${ }^{14} \mathrm{C}$ emissions in some NPPs during temporary shutdown periods (e.g. Slovakia), is highlighted in Figure 3. The strong variability in emission factors $\left(\mathrm{R}^{2}\right.$ of regression line is 0.09) for the European PWR reactors might be explained by the variety of operating procedures (e.g. power production, shutting down, maintenance, testing, refueling) adopted by each nuclear plant. Different techniques employed for the emission measurements and related uncertainties may affect the emission factor variance as well. However, neither the measurement techniques used nor the data precision were reported in the RADD database and therefore could not be assessed. Standardized information on the operating procedures adopted by each plant or on specific shutdown periods were also not provided. Nevertheless, the variation in annual ${ }^{14} \mathrm{C}$ emission factors is narrowed down when the mean of the total ${ }^{14} \mathrm{C}$ emission values over the whole time period for each reactor is plotted against the averaged power production (Figure $4 ; \mathrm{R}^{2}$ of 0.59 ). This suggests that higher capacity reactors do produce more ${ }^{14} \mathrm{C}$ emissions, consistent with the emission factor model, even though year-to-year variations may not be well-explained by power production (Figure 3). An alternate model of ${ }^{14} \mathrm{C}$ emissions using the emission factors in Table 1 with the reactor capacity, neglecting year-to-year variations in power production, may provide (time-invariant) estimates of ${ }^{14} \mathrm{C}$ emissions with similar skill as the emission factor model applied to annual power production data. 


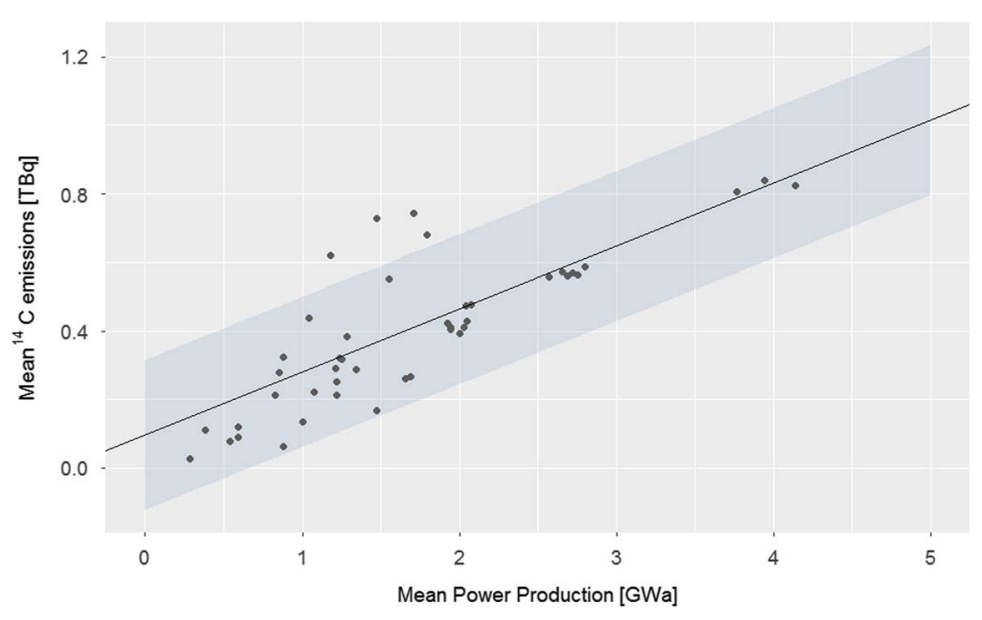

Figure 4 Mean ${ }^{14} \mathrm{C}$ emission versus mean power production for European PWR reactors over 1995-2015. The line represents a linear regression with $R^{2}$ of 0.59 and the shaded area the standard deviation.

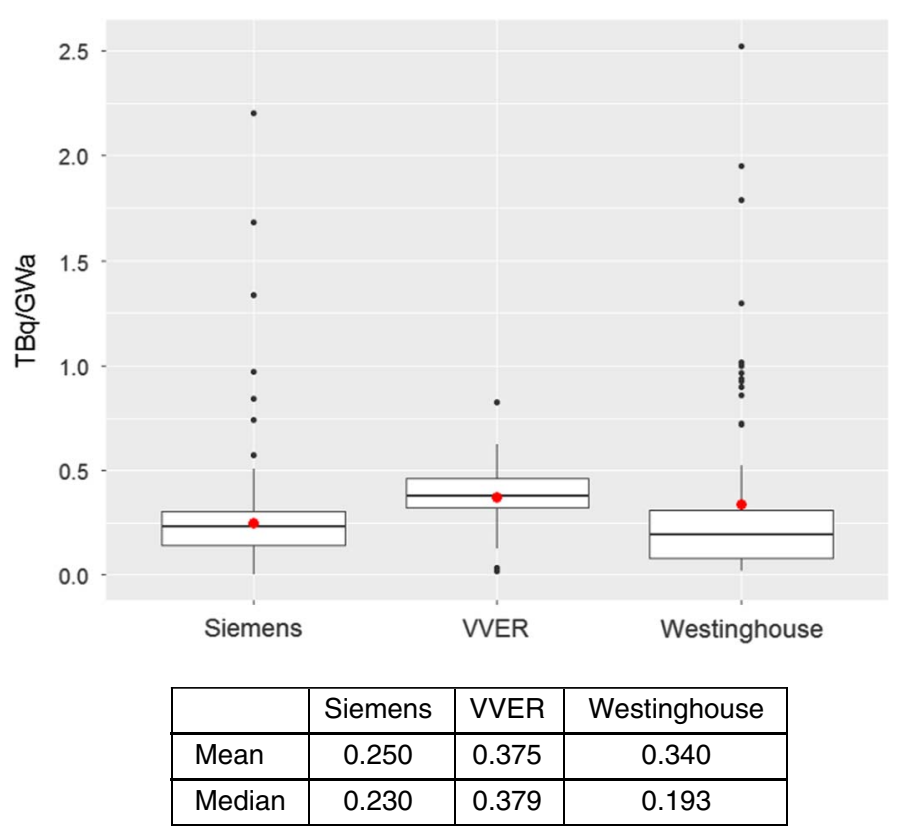

Figure 5 Emission factors for PWRs from different manufacturers. Mean values are indicated in red circles.

Figure 5 shows the emission factors for three PWR manufacturers: Siemens, VVER, and Westinghouse. A fourth manufacturer, Areva, produced all of the reactors in France. Since we found that the ${ }^{14} \mathrm{C}$ emissions from France were likely to be based on a standard emission factor of $0.209 \mathrm{TBq} / \mathrm{GWa}$, we exclude the French Areva reactors from the analysis here.

Most of the reactors within the same nuclear facility are built by the same manufacturer, which allowed allocating each nuclear site to one manufacturer. Areva and Siemens are based on a 


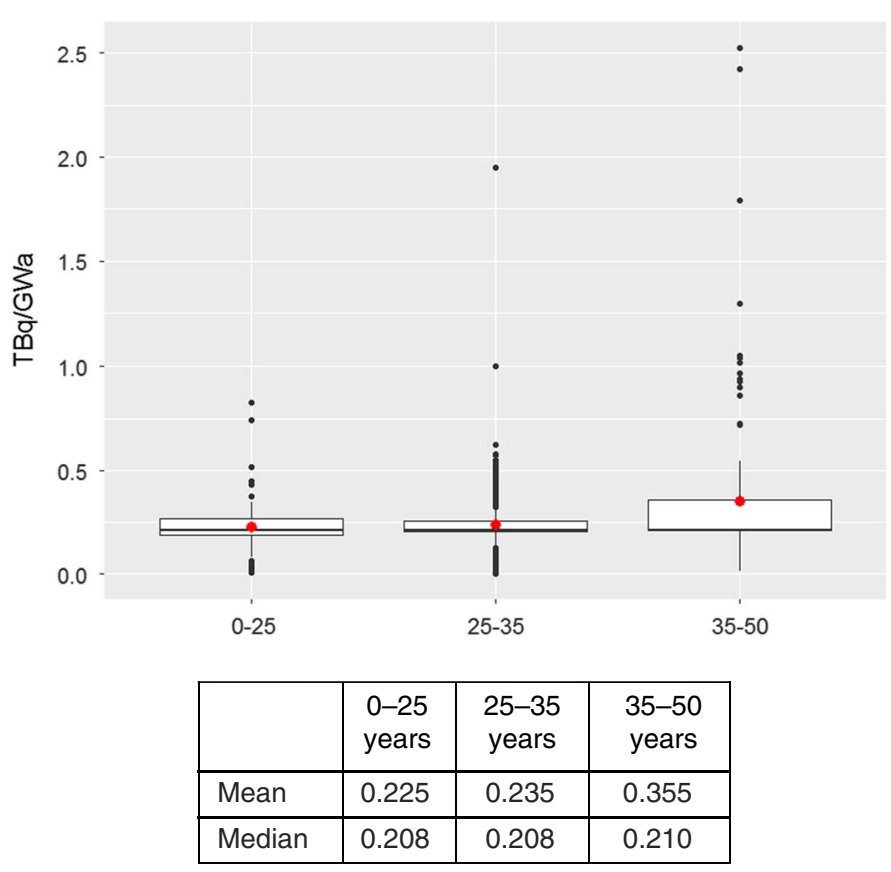

Figure 6 Age-based emission factors for the period 1995-2015. Mean values are indicated in red circles.

licensed Westinghouse design, so these three manufacturers use similar technical specifications, whereas the Soviet-design VVER reactors are substantially different in the components of the primary system and in the safety measures implemented (Cacuci 2010). The use of a larger volume of coolant and nitrogen solutes as chemical regulators in the primary system of VVERs may result in a larger production of ${ }^{14} \mathrm{C}$ via the ${ }^{14} \mathrm{~N}(\mathrm{n}, \mathrm{p}){ }^{14} \mathrm{C}$ reaction. Newer VVER models have incorporated more features from the western-type reactors; however, more advanced VVER designs are operating mostly in Russia, and are not reported in the RADD database. Only up to generation-2 VVER reactors are operating in Europe and included in the analysis. Siemens-manufactured PWRs were built mostly in Germany, whereas Westinghouse-manufactured reactors were built in Slovenia, Spain, Sweden and the UK. While the mean emission factor for Westinghouse is higher than for Siemens, the median value of $0.193 \mathrm{TBq} / \mathrm{GWa}$ is similar. In particular, emission factors from the Swedish Westinghouse reactor Ringhals 2 are notably higher ( $>1 \mathrm{TBq} / \mathrm{GWa}$, Figure S2), and are apparent in Figure 5 as outliers.

The analysis of ${ }^{14} \mathrm{C}$ emissions from European PWR reactors of different ages is shown in Figure 6. Younger reactors seem to produce less ${ }^{14} \mathrm{C}$ per $\mathrm{GWa}$ of electricity produced, as would be expected since they use newer technologies and adhere to environmental standards put in place more recently (IAEA PRIS 2017). However, older reactors might have been updated throughout the period of study and their emission factor reduced. Again, median values are more similar than mean values across the three types, therefore emissions factors distributions cannot be consider statistically different.

\section{Emissions of ${ }^{14} \mathrm{CO}_{2}$ and ${ }^{14} \mathrm{CH}_{4}$}

Only Germany, Spain, Slovakia, and Hungary differentiate total gaseous ${ }^{14} \mathrm{C}$ effluents in ${ }^{14} \mathrm{CO}_{2}$ and ${ }^{14} \mathrm{CH}_{4}$ emissions. ${ }^{14} \mathrm{CH}_{4}$ and ${ }^{14} \mathrm{CO}_{2}$ emissions measurements from the PWR reactors within 

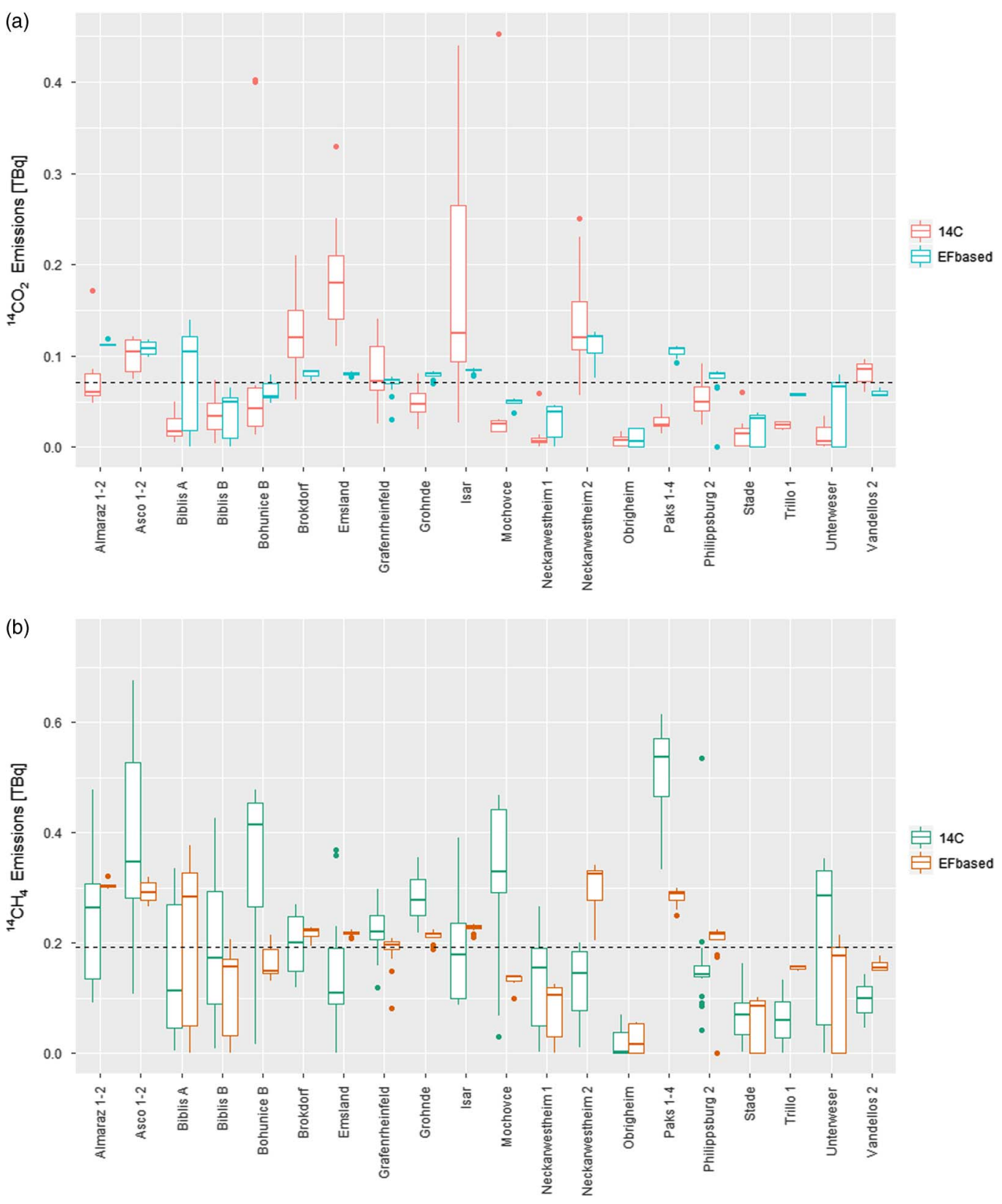

Figure 7 Observed and emission factor based ${ }^{14} \mathrm{C}$ values for (a) $\mathrm{CO}_{2}$ and (b) $\mathrm{CH}_{4}$ emissions, estimated using a $72 \%$ $\mathrm{CH}_{4}$ fraction. The dotted line is the mean value of all the ${ }^{14} \mathrm{C}$ measurements (RADD database).

these countries have been compared to the emission factor based estimates, and to the mean ${ }^{14} \mathrm{CH}_{4}$ and ${ }^{14} \mathrm{CO}_{2}$ emissions over all reactors (Figure 7).

Based on the measurements for 1995-2015 from reactors in the aforementioned countries, we calculated an average fraction of ${ }^{14} \mathrm{CH}_{4}$ of $72 \%$ for PWR and $0.5 \%$ for BWRs. These 


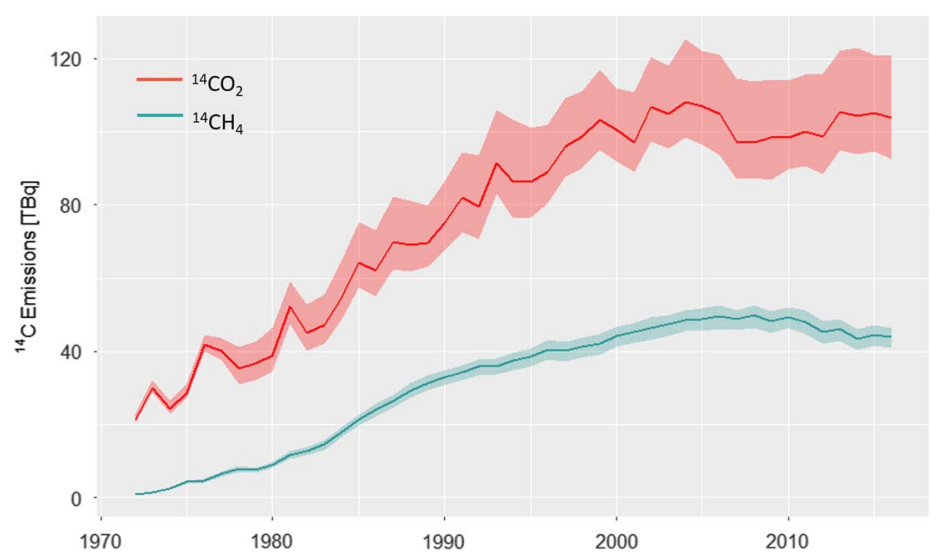

Figure 8 Global ${ }^{14} \mathrm{CO}_{2}$ and ${ }^{14} \mathrm{CH}_{4}$ emissions from NPPs and from Sellafield, La Hague, and Tokai reprocessing sites for the period 1972-2016. A fraction of $72 \%$ of ${ }^{14} \mathrm{C}$ released as $\mathrm{CH}_{4}$ from the PWRs has been used in the estimation, with all other ${ }^{14} \mathrm{C}$ released in the form of $\mathrm{CO}_{2}$. Uncertainties are based on Monte Carlo simulations using the log-normal distributions of emission factors from Table 1. Errors in the ${ }^{14} \mathrm{C}$ emissions from reprocessing plants are not included.

are similar to other studies that observed a ${ }^{14} \mathrm{CH}_{4}$ fraction in a range within 57 and $93 \%$ for PWRs and a fraction of $0.5 \%$ for BWRs (Kunz 1985; Uchrin et al. 1997).

Similar to the total ${ }^{14} \mathrm{C}$ emissions (Figure 3), we find a large range of ${ }^{14} \mathrm{CH}_{4}$ and ${ }^{14} \mathrm{CO}_{2}$ emissions in the measurements and the emission factor-based estimates. However, we do find that the emission factor-based estimates represent the measured emissions better than the simple average of ${ }^{14} \mathrm{CH}_{4}$ and ${ }^{14} \mathrm{CO}_{2}$ emissions over all reactors does (Figure 7). The root mean square error between the measured ${ }^{14} \mathrm{CO}_{2}$ emissions and the emission factor based estimates is $0.149 \mathrm{TBq}$, compared to a root mean square error of $0.161 \mathrm{TBq}$ for the average emissions of the ${ }^{14} \mathrm{C}$ measurements from the PWR reactors $(0.071 \mathrm{TBq})$. For ${ }^{14} \mathrm{CH}_{4}$ emissions, the root mean square error is also lower for the emission factor based ${ }^{14} \mathrm{CH}_{4}$ estimates than for the average emissions (0.192 TBq), 0.076 and $0.081 \mathrm{TBq}$ respectively. This suggests that the use of the emission factor approach is more suitable than using a constant ${ }^{14} \mathrm{C}$ emission per reactor type.

Based on this analysis, we assume that $72 \%$ of ${ }^{14} \mathrm{C}$ released from PWRs is ${ }^{14} \mathrm{CH}_{4}$, with the rest of the emissions from all reactor types as ${ }^{14} \mathrm{CO}_{2}$, and we calculate global emissions of ${ }^{14} \mathrm{CH}_{4}$ and ${ }^{14} \mathrm{CO}_{2}$ (Figure 8). To calculate uncertainty we conducted 600 Monte Carlo simulations to estimate emissions from each reactor using the estimated log-normal distributions of emission factors (Figure 1, Graven and Gruber 2011). The number of simulations has been chosen in order to obtain a converged standard deviation (Rochman et al. 2014). The filled area in Figure 8 shows the interquartile range of the estimates for each year.

Global estimates of ${ }^{14} \mathrm{CO}_{2}$ show a reduction after 2005 concomitant with the closure of the UK GCR-type reactors (Figure 1) and decreasing emissions from some other reactor types. However, after 2011, the reduction is counteracted by the relatively large increase in ${ }^{14} \mathrm{C}$ emissions from reprocessing plants, in particular La Hague in France. Estimated ${ }^{14} \mathrm{CH}_{4}$ emissions show a decreasing trend only after 2011, following the decrease in PWR power output from the shutdown of PWRs after the Fukushima accident. During the last three years $\mathrm{CH}_{4}$ emissions seem to be approximately constant. Overall, the growth in global emissions of ${ }^{14} \mathrm{CH}_{4}$ and ${ }^{14} \mathrm{CO}_{2}$ that characterized the 1970 s to early 2000 s appears to have stopped in the last $10-15$ years. 


\section{CONCLUSIONS}

Global ${ }^{14} \mathrm{C}$ emissions appear to have peaked in the mid-2000s and then decreased slightly as a result of some European and Japanese NPPs shutting down. The shutdown of UK Magnox GCR-type reactors after 2005 played a key role in the ${ }^{14} \mathrm{CO}_{2}$ emission reduction, as they have the highest emission factor. As global PWR energy output decreased after $2010,{ }^{14} \mathrm{CH}_{4}$ emissions are also expected to have decreased in the past 7 years. While our estimates have large uncertainties, it is unlikely that global ${ }^{14} \mathrm{CH}_{4}$ or ${ }^{14} \mathrm{CO}_{2}$ emissions increased substantially over the past 10 years. Therefore, atmospheric studies of ${ }^{14} \mathrm{CH}_{4}$ or ${ }^{14} \mathrm{CO}_{2}$ should account for this inflection point in the growth of ${ }^{14} \mathrm{C}$ emissions over previous decades. At the same time, regional shifts in emissions have occurred, with emissions increasing in China and India but remaining steady or decreasing elsewhere. It is not clear how ${ }^{14} \mathrm{CH}_{4}$ or ${ }^{14} \mathrm{CO}_{2}$ emissions will change in the future. There are 57 NPPs currently in construction, primarily in Asia (IAEA PRIS 2017), which are nearly all PWR types. Future projections in nuclear energy production in the shared socioeconomic pathways (Riahi et al. 2017) show both increases and decreases in different scenarios. Some strong greenhouse gas mitigation scenarios show nuclear energy production increasing more than 10-fold by the end of the century (SSP Public Database 2017).

Our analysis shows strong variability in observed ${ }^{14} \mathrm{C}$ emission factors for European NPPs, spanning values from 0.003 to $2.521 \mathrm{TBq} / \mathrm{GWa}$ for PWR and from 0.007 to $1.732 \mathrm{TBq} / \mathrm{GWa}$ for BWR reactors for the period 1995-2015. The values used in Graven and Gruber (2011) of 0.24 and $0.51 \mathrm{TBq} / \mathrm{GWa}$ for PWR and BWR reactors, respectively, based on observations from 1990-1995, and theoretical ${ }^{14} \mathrm{C}$ production rates of 0.3 for PWRs and 0.6 for BWRs TBq/GWa (Yim and Caron 2006) are within these ranges. The value of $0.286 \pm 0.026 \mathrm{TBq} \mathrm{GWe}^{-1} \mathrm{yr}^{-1}$ for PWR reactors calculated by Lassey et al. (2007b) is also consistent with our range. Emission factors for American PWR reactors (US NRC 2016) calculated based on the EPRI recommendations (EPRI 2010) are also within these ranges, but have a somewhat higher median value of $0.4 \mathrm{TBq} / \mathrm{GWa}$.

Average ${ }^{14} \mathrm{C}$ emissions observed at the European sites show a correlation with their average power production over 1995-2015, but year-to-year variations in observed ${ }^{14} \mathrm{C}$ emissions do not show a strong correlation with year-to-year variations in energy production. Previous studies have shown that emissions can be elevated during outage periods, effectively showing the opposite relationship as assumed in the emission factor approach. We found that intrinsic characteristics of nuclear reactors such as age and manufacturer did not explain the observed variability, except for VVER-type PWRs that have higher emissions. Mean emission factors from older reactors (35-50 years old) are slightly higher $(0.36 \mathrm{TBq} / \mathrm{GWa})$ than younger reactors, but median values are nearly the same $(0.21 \mathrm{TBq} / \mathrm{GWa})$.

We have applied the power-based emission factor approach to estimate ${ }^{14} \mathrm{C}$ emissions from individual power plants because observations of ${ }^{14} \mathrm{C}$ emissions are only available for a small number of sites and the emission factor approach is the only model available. While the use of power-based emission factors is likely to provide a reasonable estimate of global ${ }^{14} \mathrm{C}$ emissions on interannual timescales, power-based emission factors might lead to spurious estimates in some regions over shorter timescales. A better understanding of variations in ${ }^{14} \mathrm{C}$ emissions and a model that can predict such variability are needed. The model from EPRI (2010), which is based on theoretical calculations and limited data not including the European data we use here, could be implemented for the European reactors and refined by comparing estimated ${ }^{14} \mathrm{C}$ emissions with recent measurements reported in RADD Database (2017). Information on temporary shutdown and venting periods and more finely resolved electricity production and ${ }^{14} \mathrm{C}$ emissions data would help to identify patterns of ${ }^{14} \mathrm{C}$ emissions. 


\section{ACKNOWLEDGMENTS}

This project has received funding from the European Research Council (ERC) under the European Union's Horizon 2020 research and innovation programme (grant agreement No 679103), and from a European Union FP7 Career Integration Grant.

\section{SUPPLEMENTARY MATERIAL}

To view supplementary material for this article, please visit https://doi.org/10.1017/RDC.2018.42

\section{REFERENCES}

Cacuci DG. 2010. Handbook of Nuclear Engineering. Vol. 1: Nuclear Engineering Fundamentals; Vol. 2: Reactor Design; Vol. 3: Reactor Analysis; Vol. 4: Reactors of Generations III and IV; Vol. 5: Fuel Cycles, Decommissioning, Waste Disposal and Safeguards. Springer Science \& Business Media.

Dubourg M. 1998. The carbon-14 cycle XA9848078. Gas Cooled Reactor Decommissioning, Fuel Storage and Waste Disposal 138:233.

Eisma R, Vermeulen AT, van der Borg K. 1995. ${ }^{14} \mathrm{CH}_{4}$ emissions from nuclear power plants in northwestern Europe. Radiocarbon 37(2):475-83.

EPRI. 2010. Estimation of carbon-14 in nuclear power plant gaseous effluents. TR-1021106.

Graven HD, Gruber N. 2011. Continental-scale enrichment of atmospheric ${ }^{14} \mathrm{CO}_{2}$ from the nuclear power industry: potential impact on the estimation of fossil fuel-derived $\mathrm{CO}_{2}$. Atmospheric Chemistry and Physics 11(23):12339-49.

Graven HD et al. 2012. Observations of radiocarbon in $\mathrm{CO}_{2}$ at La Jolla, California, USA 1992-2007: Analysis of the long-term trend. Journal of Geophysical Research: Atmospheres 117(D2).

IAEA PRIS. 2017. Country statistics. Available at https:// www.iaea.org/pris/ (date of access: 30/10/2017).

IPCC. 2013. Climate Change 2013: The Physical Science Basis. In: Stocker TF, et al., editors. Contribution of Working Group I to the Fifth Assessment Report of the Intergovernmental Panel on Climate Change. Cambridge (UK): Cambridge University Press. 1535 p.

Kirschke S et al. 2013. Three decades of global methane sources and sinks. Nature Geoscience 6(10):813.

Kunz C. 1985 . Carbon-14 discharge at three lightwater reactors. Health Physics 49(1):25-35.

Lassey K, Etheridge DM, Lowe DC, Smith AM, Ferretti DF. 2007a. Centennial evolution of the atmospheric methane budget: what do the carbon isotopes tell us? Atmospheric Chemistry and Physics 7(8):2119-39.

Lassey K, Lowe DC, Smith AM. 2007b. The atmospheric cycling of radiomethane and the "fossil fraction" of the methane source. Atmospheric Chemistry and Physics 7(8):2141-9.

Levin I, Kromer B, Schmidt M, Sartoriuset H. 2003. A novel approach for independent budgeting of fossil fuel $\mathrm{CO} 2$ over Europe by ${ }^{14} \mathrm{CO}_{2}$ observations. Geophysical Research Letters 30(23).
Levin I, Hammer S, Kromer B, Meinhardt F. 2008. Radiocarbon observations in atmospheric $\mathrm{CO}_{2}$ : determining fossil fuel $\mathrm{CO}_{2}$ over Europe using Jungfraujoch observations as background. Science of the Total Environment 391(2-3):211-6. doi: 10.1016/ j.scitotenv.2007.10.019.

Miller JB et al. 2012. Linking emissions of fossil fuel $\mathrm{CO}_{2}$ and other anthropogenic trace gases using atmospheric ${ }^{14} \mathrm{CO}_{2}$. Journal of Geophysical Research 117:D08302. doi: 10.1029/2011JD01 7048.

Molnár M, Bujtás T, Svingor É, Futó I, Světlíket I. 2007. Monitoring of atmospheric excess ${ }^{14} \mathrm{C}$ around Paks nuclear power plant, Hungary. Radiocarbon 49(2):1031-43.

Nakada A et al. 2008. Radioactive Airborne Effluent Discharged from Tokai Reprocessing Plant 19982007. Japan Atomic Energy Agency.

Nisbet E, et al. 2016. Rising atmospheric methane: 2007-2014 growth and isotopic shift. Global Biogeochemical Cycles 30(9):1356-70.

Quay P, Stutsman J, Wilbur D, Snover A, Dlugokencky E, Brown T. 1999. The isotopic composition of atmospheric methane. Global Biogeochemical Cycles 13(2):445-61.

RADD Database. 2017. Available at http://europa.eu/ $\mathrm{radd} /$ nuclideDischargeOverview.dox?pageID $=\mathrm{Nu}$ clideDischargeOverview (date of access: 16/10/ 2017).

Riahi K et al. 2017. The Shared Socioeconomic Pathways and their energy, land use, and greenhouse gas emissions implications: an overview. Global Environmental Change 42:153-68. doi: https://doi.org/10.1016/j.gloenvcha.2016.05.009.

Rochman D. 2014. Efficient use of Monte Carlo: uncertainty propagation. Nuclear Science and Engineering 177(3):337-49.

Rogelj J et al. 2016. Paris Agreement climate proposals need a boost to keep warming well below $2{ }^{\circ} \mathrm{C}$. Nature 534(7609):631-9.

Schwietzke S. 2016. Upward revision of global fossil fuel methane emissions based on isotope database. Nature 538(7623):88-91.

Shindell D. 2012. Simultaneously mitigating nearterm climate change and improving human health and food security. Science 335(6065):183-9.

SSP Public Database. 2017. Version 1.1, available at https://tntcat.iiasa.ac.at/SspDb (date of access: 29/08/2017). 
Stenström K. 1995. A one-year study of the total airborne ${ }^{14} \mathrm{C}$ effluents from two Swedish light-water reactors, one boiling water-and one pressurized water reactor. Journal of Radioanalytical and Nuclear Chemistry 198.1(1995):203-13.

Stuiver M, Polach HA. 1977. Discussion: reporting of ${ }^{14} \mathrm{C}$ data. Radiocarbon 19(3):355-63.

Turnbull J, Rayner P, Miller J, Naegler T, Ciais P, Cozic A. 2009. On the use of ${ }^{14} \mathrm{CO}_{2}$ as a tracer for fossil fuel $\mathrm{CO}_{2}$ : quantifying uncertainties using an atmospheric transport model. Journal of Geophysical Research: Atmospheres 114(D22).

Uchrin G, Hertelendi E, Volent G, Slavik O, Morávek J, Kobal I, Vokal B. 1997. ${ }^{14} \mathrm{C}$ measurements at PWRtype nuclear power plants in three middle European countries. Radiocarbon 40(1):439-46.

UNSCEAR. 2000. Sources and Eeffects of Ionizing Radiation. Report of the United Nations Scientific
Committee on the Effects of Atomic Radation, Vienna.

US NRC. 2016. Radioactive Effluent and Environmental Reports. Available at: https://www.nrc. gov/reactors/operating/ops-experience/tritium/plantinfo.html (date of access: June 2016).

Van der Stricht S, Janssens A. 2001, 2005. Radioactive Effluents from Nuclear Power Stations and Nuclear Fuel Reprocessing Sites in the European Union. Radiation Protection, European Commission.

Vogel FR, Levin I, Worthy DEJ. 2013. Implications for deriving regional fossil fuel $\mathrm{CO}_{2}$ estimates from atmospheric observations in a hot spot of nuclear power plant ${ }^{14} \mathrm{CO}_{2}$ emissions. Radiocarbon 55(3):1556-72.

Yim M-S, Caron F. 2006. Life cycle and management of carbon-14 from nuclear power generation. Progress in Nuclear Energy 48(1):2-36. 